\title{
El juego del título en la poesía de Eduardo García
}

\author{
Pedro Ruiz PÉrez \\ Universidad de Córdoba
}

\begin{abstract}
Desde Las cartas marcadas (1993) a Duermevela (2014), la poesía de Eduardo García (1965-2016) traza un recorrido muy sintomático de la poética hispana del cambio de siglo, desde el entorno de la poesía de la experiencia a la experiencia de los límites donde la realidad se desdobla. A lo largo de sus seis poemarios, intercalados por un manual de escritura y un ensayo de poética, el manejo de los mecanismos del título (del poema y del libro) se revela, más allá de la condición de síntoma, como un factor agente en el juego de hacer versos, sin que en este punto suponga variación el desplazamiento de la mirada de las Moralidades de Gil de Biedma al Don de la ebriedad de Claudio Rodríguez.
\end{abstract}

Keywords: Eduardo García, título, poética, crítica genética

\section{El título no ha existido siempre}

Los textos que hemos integrado en la serie de escritos literarios procedentes de la época medieval temprana carecen en no pocas ocasiones, como es sabido, de firma. Se repara menos en que los manuscritos que los contienen también suelen carecer de título, siendo esta una práctica muy frecuente (Gonzalo Sánchez-Molero 20I6). El incipit era la marca que en la primera página señalaba el comienzo del texto, y su expresión era analítica y descriptiva, incluyendo con cierta normalidad la mención del dedicatario de la obra y la intención de su componedor. A falta de firma, el explicit servía de cierre, generalmente momentáneo, a un texto donde la apertura era un rasgo habitual. Si en otra ocasión he postulado el papel de la rúbrica en la constitución de la figura autorial y, con ella, del texto plenamente literario (Ruiz Pérez 2009), cabe aquí una consideración paralela del título, el otro elemento que acabará imponiéndose en el libro impreso. En España la normativa derivada de la pragmática de 1559 impulsada por Felipe II convertía esos dos elementos en obligados en la primera página de los productos editoriales (Reyes Gómez 2000). Sin embargo, la sanción regia no venía a inducir una práctica, sino que era la pauta de normalización y de normatividad de lo que ya se iba imponiendo como un uso extendido. La firma (Kamuf I988) identificaba al autor, y el título hacía lo propio con el texto (Hoek I98I). La primera implicaba una marca de procedencia y, de manera matizada, de propiedad. El segundo dotaba a la obra de su entidad como tal, en un doble juego que la inscribía en una serie (genérica o, en sentido más lato, literaria) y la singularizaba. 
Este valor definitorio, que acompañaba a la obra plenamente literaria y jugaba un papel importante en su conformación como tal, históricamente se impone primero con un sentido de adscripción de la obra a un conjunto conocido y reconocible (Infantes 1998-2004). Así ocurre con los rótulos genéricos que, entre los siglos XVI y XVII, encabezaban los volúmenes de rimas (García Aguilar 2008), los infolios caballerescos o los impresos en formato más reducido de las cadenas picaresca o de colecciones de novela corta. Solo la consolidación del campo literario, la competencia en el mercado y la voluntad de distinción que se traduce románticamente en prurito de originalidad llevan la rotulación de las obras literarias a su etapa siguiente, cuando buscan desde la portada atraer al lector comprador con un título singular, promesa de un contenido novedoso. Más allá del juego creativo de la intertextualidad, los títulos de carácter formulístico quedaban como rasgos propios de la llamada «literatura de género», con su connotación de adocenada y sin otras pretensiones que llenar un espacio de ocio en clave de consumo de productos fácilmente digeribles.

Esta breve ojeada histórica sirve para recordar que, como la literatura, el título no ha existido siempre, ni lo ha hecho a través de siglos y géneros con el mismo valor y funcionalidad. Pero, sobre esta obviedad, se perfila una vía de acceso a la consideración de una titrologie (Duchet 1973) no solo actualizada en sus perspectivas históricas y funcionalistas, sino también ajustada al análisis de la rotulación de la poesía, tanto en lo que se refiere a la unidad libro como en lo tocante a la unidad poema, ya que podemos trasladar al plano de la pieza las mismas consideraciones apuntadas para el poemario. Sirva considerar en el nivel del microtexto los marbetes habituales en los manuscritos cancioneriles, apelando en su práctica totalidad a una caracterización genérica («glosa», «desfecha», «coplas»...), acompañada en ocasiones con una mención al autor («otra del mismo»). La repetición y la serialidad se imponían, aunque en diverso modo, en la práctica versificatoria del salón cortesano y en su traslación al cancionero caligrafiado. Poco cambiaría en este punto la formalización impresa del volumen de versos, ya se tratase de la forma orgánica del cancionero al modo petrarquista, ya fuese la simple compilación de «rimas» sin un hilo estructurante. En la mayor parte de los casos bastaba el simple recurso a la numeración, acompañada o no de la referencia métrico-genérica del poema («égloga III»). Cuando, bien avanzado el siglo Xviı y al hilo de la creciente publicación de una poesía circunstanciada, se incluyen rótulos con un efecto más distintivo, estos se limitan a informar sobre el origen o el marco de los versos, recomponiendo con valor informativo un contexto que no pocas veces también incurría en un tópico, perfectamente reconocible para los lectores: «Yendo a ver a Lisi, llovió y nevó mucho, cogiéndolo a Fabio la tempestad en la calle» (Félix Lucio de Espinosa y Malo, Ociosidad ocupada y ocupación ociosa I674: 28), «A 
una señora que se había sangrado, aludiendo a la precisión de regalarla» (Eugenio Gerardo Lobo, Obras poéticas I729: 223) (Martín Puya \& Ruiz Pérez 20I5). Con un claro valor referencial, aparentemente singularizador, el rótulo operaba en el fondo con un efecto de clasificación, esto es, de inclusión del poema en una clase reconocible, tan marcada por los modelos como por la repetición. La práctica denotaba al mismo tiempo el carácter inorgánico de las unidades poemáticas, surgidas al hilo de las circunstancias y sin un designio unitario, y su subordinación al marco artificioso y postrero del libro. En un horizonte dominado por el principio de varietas, el incipiente modo de titulación (más bien, su ausencia) denotaba las peculiares relaciones entre el poema y el marco compilatorio, aunque también habría que hablar aquí de una ausencia.

Respecto a lo observable en la novela, en el campo de la poesía nos encontramos con un período de espera más amplio hasta el acercamiento a un uso de los títulos en libros y poemas cercano al que mantiene su actualidad en el centro del canon. Sabido es que fue el simbolismo del último tercio del siglo xIX el que redefinió la naturaleza del poema y planteó la concepción del volumen de poesía con un sentido unitario o, cuando menos, orgánico, con diferencias entre las sucesivas entregas que un mismo poeta puede hacer en el discurso de su vida. Y con esta transformación cabe ya encontrarse con un uso de los títulos igualmente emparentado con los vigentes cuando hemos atravesado el umbral del siglo xxi. De nuevo estas observaciones se dirigen a un propósito menos conceptual que metodológico. Si bien el título de un libro o de un poema puede (y debe) considerarse en su condición específica e individual, hay que mantener presente la condición sistemática de la titulación, en una red de relaciones que vinculan los epígrafes de las piezas entre sí y todas y cada una de ellas con el rótulo que define su agrupación en un volumen. Si en términos lingüísticos (Dijk 1980) no cabe hablar siempre de cohesión, sí hay que considerar una premisa obligada la coherencia del conjunto de títulos que encontramos en la cabecera y en el índice de un libro de poesía, por lo que el sentido último de lo apuntado por un título singular se alcanza en el marco en que se inscribe.

Otras consideraciones se desprenden de esta perspectiva histórica en la que el título no aparece como algo connatural a la escritura del poema o, al menos, no lo ha sido siempre. Y este carácter artificial, artístico si se quiere, lleva nuestra mirada a su condición, a su posición en el poema y a las funciones que conlleva. El título despliega su potencial de sugerencia por su condición generalmente sintética y por la doble naturaleza de la síntesis que opera en su formulación; de una parte, se trata de una formulación abreviada, comprimida, que puede renunciar (y con frecuencia lo hace) a su valor denotativo, para entrar en el campo de la connotación, digno heredero también en esto de la matriz simbolista; de otra parte, ya que no como re- 
sumen, el título queda conformado a modo de extracto, de precipitado de lo que el poema ha desplegado o como germen del que brotarán los versos que siguen, según se trate de un marco puesto a posteriori para el texto del poema, ya se trate de la imagen que le da origen. En uno y en otro caso el título avanza sobre la condición sintética del fragmento lírico, en relación a los géneros discursivos o narrativos, y en la antesala del mismo se erige como una miniatura microtextual. Tal condición contribuye a la intensidad con que cumple sus funciones respecto al poema, actuando como clave para indicar un punto de entrada en su espacio, como foco que condensa la mirada sobre uno de los componentes del texto o como contrapunto que desdobla la posible lectura.

\section{Una aproximación}

Vengamos en este punto a la poesía de Eduardo García', para señalar los casos cuya observación, en abierto diálogo con las consideraciones sobre la naturaleza histórica del título, sirve de base a estas hipótesis. El título más breve de todos los suyos nos da la idea de esa llave pequeña que abre espacios que pueden llegar a ser vertiginosos. Se trata del que rotula este poema de Duermevela (2014):

ECO

En tu fotografía hay un remoto fulgor de otro verano, ágil revuelo, un destello, tal vez, de fiebre contenida, al filo de una rama, ya a punto de saltar, centellea, frescor inesperado despuntando en el alba, tu sonrisa, el eco de un hervor bajo la piel ya se apacigua en la pantalla.

Al levantar la vista te miro ensimismada, prende el aire, se incendia el calendario en el atardecer, tiembla en tus ojos la llama de una vela, se refleja un bullicio de espumas, cruzan pájaros el eco de las islas sumergidas: sorprendo, remontando el vuelo, despuntando en tu piel, rumbo al mañana, un destello de fiebre del ayer.

I Una información más precisa sobre su obra se encuentra en el apartado siguiente. 
En forma comprimida el título del poema señala el campo semántico dominante en el poema, donde se agrupan, entre otros, términos como «fotografía», «fulgor», «destello», «pantalla» o «refleja», junto con las expresiones que traen imágenes de desdoblamiento («otro verano» o «tiembla en tus ojos / la llama de una vela»), entre el reflejo y el juego de espejos. El campo sensorial dominante es el de la vista, sobre todo en la segunda parte («vista», «miro», «ojos»...); en el entrecruzamiento de planos se impone la no mencionada imagen de «reverberación», aplicable a los efectos visuales y a los de sonido, que, al ser evocados en el título, asientan la clave sinestésica del poema, intensificada por las impresiones térmicas («fiebre», «frescor», «hervor», «prende», «incendia», «llama»...); la repetida referencia a «fiebre» (vv. 3 y i7) enlaza las dos partes del poema de manera explícita, como lo hace la propia voz que se ha elevado al título (vv. 7 y I4); al destacarse, se reequilibra cualitativamente lo que se había desestabilizado en el orden cuantitativo del léxico y se otorga profundidad a un poema que comienza con la presencia de la fotografía (imagen duplicada, también ficcional, por mimética) y se cierra con la referencia a una «fiebre» que vuelve desde el ayer, como un eco, síntoma, a su vez, de algo más profundo, pura imagen de la enfermedad o el desasosiego, eco del malestar. De hecho, la primera aparición de «eco» (v. 7) es para acompañar a un sinónimo de fiebre o a una perífrasis que alude a ella, trayendo la piel como una metáfora de la pantalla. En su segunda recurrencia, el término «eco» acompaña a «islas sumergidas», disparando, por insistir en la idea, ecos multiplicados de referencias en clave literaria y de la propia obra del autor. En la tercera sección del mismo libro, la que comparte título con la del conjunto de la obra, encontramos otro poema con el mismo título, más breve y de referencia más explícita:

\section{ECO}

Cuando la muerte asoma

palidecen de miedo las palabras.

Cuando el amor os mece

su fulgor centellea en las palabras.

Todo lo roba el tiempo.

Pero nos deja su eco, prendido en las palabras.

El paralelismo de las dos primeras estrofas, con la dualidad thánatos y eros, incide en la idea de eco ya anunciada en la repetición. En la segunda estrofa reaparecen palabras e imágenes del poema previo. Y, finalmente, en el par de versos finales aparece explícito el «eco», con su valor de reverberación y permanencia. No es el único juego de ecos intertextuales, si se me 
permite el concepto. Justamente el mismo año de 2014 salía a la luz el libro de aforismos que la editorial granadina Cuadernos del Vigia le publicaba al autor justamente con este título, Las islas sumergidas; su aparición en febrero permite pensar que los lectores del poeta que acceden a Duermevela pueden tener sobrada noticia de la publicación previa y, quizá, una lectura de sus textos, en una trama de referencias e imágenes en diálogo, tal como ocurre en el espacio onírico de la duermevela, identificable con esa forma de oxímoron, si no extraordinaria revelación, de una isla sumergida. La evocación del iceberg, con su juego de espejo cóncavo, por el que la parte superficial es un mero síntoma de la realidad bajo el agua, reformula la imagen de desdoblamientos y ecos, de repeticiones difractadas, tan propias de la duermevela, que es también el título de la sección del libro en que se incluye el poema. El propio poema, con su bipartición y el intencionado juego de los encabalgamientos (que dejan versos bimembres y de desequilibrada semántica), recoge en su propia materialidad la materia de que trata y que encuentra en «Eco» una acertada síntesis, en clara disponibilidad para potenciar los efectos de lectura, entre la referencialidad y la sugerencia o la evocación.

Valor de foco es el que podemos apreciar en el título de este otro poema:

\section{DEPREDADOR}

\author{
Como el gato se mira en el espejo \\ y no se reconoce ni comprende \\ la hostil ferocidad agazapada \\ del gato que le mira, \\ del intruso,
}

yo contemplo los ojos de la gente a la que no sé amar, perplejo por el civilizado desafío que refulge, voraz, en esos ojos.

Y no me reconozco en el intruso.

Perteneciente a Refutación de la elegía (2006), este poema adelanta alguno de los elementos observados en «Eco», además de repetir la formulación del título mediante un escueto sustantivo (o adjetivo sustantivado). Encontramos otra vez la estructura dual, correspondiente a la temática del espejo, el desdoblamiento o el eco, que podría presentarse como metáfora y aquí lo hace como símil: «como el gato»; espejo y reflejo que apuntan a la perplejidad como sensación ante el doble. La figura es la del intruso, y el título del poema nos ayuda a concretar la relación entre esta presencia y la imagen del gato: lo que los une es su actitud de caza, destacando entre todas las po- 
sibles connotaciones o rasgos percibidos en el animal. La «hostil ferocidad» del verso 3 podía referirse a un carácter arisco. El título focaliza la mirada en el rasgo y lo especifica, evitando la polisemia y concretando lo que de amenazante hay en la realidad y la presencia del intruso. El gato que se mira en el espejo no percibe su condición de cazador; el hablante la percibe con total claridad, y el poeta explota el recurso del título para guiar la lectura. La sustantivación de una cualidad adjetiva revela la naturaleza esencial del intruso, la razón de su amenaza.

En otro poema de la mencionada sección homónima de Duermevela de nuevo un sustantivo es el que conforma el título, otorgándole a un motivo recurrente una dimensión nueva, a partir de la contraposición entre la imagen vertical del rótulo y la extensión horizontal de su correlato en el verso final:

\section{PRECIPICIO}

Soy el que llora en el espejo

y el que contempla su agonía.

Nos separa un desierto inagotable.

La dualidad esencial apuntada en los poemas previos se convierte aquí en escisión por la dimensión hiperbólica, infranqueable, del «desierto», acompañado además con un adjetivo de claro sentido borgiano y gongorinos ecos (de nuevo el término). La contraposición de imágenes espaciales entre el título y el cuerpo del poema se desdobla a partir de su equivalencia, para recuperar la antinomia: el precipicio tiene un fuerte poder de atracción e invita a asomarse, pero penetrar en su espacio deviene catástrofe; el desierto, en cambio, repele o causa apocamiento, pero puede ser atravesado $y$, aun con dificultades, puede ofrecer al otro lado la posibilidad del encuentro, la tierra prometida. Es el espejo, de nuevo, el que concentra esa doble dimensión, la del desierto evocado en la lisura de su superficie y la del precipicio que nos hunde en las entrañas del sueño o de la pesadilla, como a don Quijote en la cueva de Montesinos o a Alicia en sus aventuras.

\section{Entre el título y el nombre. Devenir Eduardo García}

Este breve repaso por un muestrario de usos del título del poema en sus distintas funciones por parte de Eduardo García nos ha mostrado como al paso, pero con un valor fundamental, la coherencia de su mirada poética, a la que volveremos brevemente más adelante. Sirva ahora su mención para apuntar cómo el empleo de los títulos se adecua a esa actitud lírica y confor- 
ma una parte determinante de su propuesta a la vez experiencial y comunicativa, mostrando de manera paradigmática el alcance que la rotulación adquiere en la composición del poema. Aparentemente en el límite, a modo de umbral, el título simula situarse en los márgenes, como si estuviera en el exterior del poema. Sin embargo, desde esa posición periférica adquiere, con el uso adecuado, una entidad a la vez propia y orientada al diálogo con lo que el poema despliega en sus versos. Lejos de la redundancia o del spoiler que cercena el vuelo del poema, el membrete que lo abre deja penetrar sus ondas de significación en el entramado del texto, interactuando con sus palabras, orientando la lectura en un movimiento de ida y vuelta. Desde su específica naturaleza, en su inseparabilidad el título se afirma como una parte del texto mismo, destacado por la tipografía y con funcionamiento propio, pero profundamente integrado en la unidad poemática. Es más, como veremos, el membrete del poema sirve también para espesar la red de relaciones que las piezas establecen entre sí y con el conjunto macrotextual del libro.

En este punto, parece oportuna una breve reflexión sobre un hecho revelador y de naturaleza paradójica. Por su condición semiótica, los mecanismos de la titulación constituyen objeto privilegiado del estudio crítico y de la especulación teórica, y así lo han sido de manera bastante cumplida (Genette 200I; Hoek I973 y I98I; Besa Camprubí 2002; Roy 2008); por la estrecha relación con el funcionamiento del poema y por la variedad de estrategias retóricas que puede establecer, merecería ser objeto de consideración de las poéticas, y, en cambio, esto no es muy frecuente, por no decir que roza la excepcionalidad. La orientación lingüística y formalista de la mayoría de los estudios, y su orientación teorética, además, dejarían generalmente al margen los aspectos pragmáticos y funcionales, que conforman el espacio más apropiado para la poética. Sin embargo, este discurso genérico no suele responder al reto. La situación se da de manera similar en los diferentes grados de sistematicidad que reconocemos en el género de la poética, desde las declaraciones más o menos obligadas, esquemáticas o de circunstancias, a las que se presentan como reflexiones de calado y con una perspectiva englobante. Podría considerarse una razón para ello que la brevedad en un caso y la pretensión holística en el otro no dejan espacio para un elemento particular y periférico, no siempre presente en el poema. Esta misma razón llevaría a pensar que sí sería un aspecto, el de la titulación, de presencia casi obligada en los manuales de escritura. A falta de una indagación más amplia en este campo, contamos con la significativa realidad de la escritura de Eduardo García, donde conviven una amplia producción de poemarios, con una sistemática aplicación del título (infra), un ambicioso y personal ensayo de poética y un manual de composición del poema de merecido reconocimiento. Sin embargo, ni en Una poética del límite (2005) ni en Escribir un poe$m a$ (2000) el lector encuentra referencias al valor y la técnica de la rotulación 
del poema. Llamativo por cuanto es uno de los problemas primarios que se plantea quien se inicia en el verso y uno de los componentes con más decisiva contribución a un cierre redondo o a un punto de descomposición. Y esto por no hablar de hasta qué punto en la caracterización de los títulos y en su juego en el espacio del libro puede concentrarse toda una declaración de intenciones poéticas. A algo de esto se acerca Eduardo Garcia en el manual de 2000 cuando plantea sus reflexiones y propuestas para el primer verso del poema, concebido en esa función de umbral y apelación que podría tener el título, pero sin mencionar este. En esas páginas (73-76) se fragua una valiosa formulación sobre los versos de apertura, cifrada en «dos condiciones»: «Sugieren mucho, es decir, se abren a muchos desarrollos posibles», "pero no revelan nada (o casi nada) de lo que vendrá después». Junto a su sugeridora potencia formativa del escritor novel, la «definición» resultante se ajustaría bastante bien a lo que hemos observado en algunos títulos escogidos de los poemas del autor. También, y esto es más significativo, si cabe, hay una concomitancia con lo que cinco años después, tras una lenta gestación, va a plasmarse en la "poética del límite», situada entre la razón denotativa y el sueño connotativo, en una forma de «duermevela» que dará título al último poemario publicado en vida y que se concretaba en una formulación intermedia en la entrega poética de 2003, Horizonte of frontera. Como el límite, los dos conceptos o imágenes que se conjugan o se contraponen en el título del libro apuntan a lo liminar, a los umbrales o seuils que en la perspectiva de Genette (200I) es la naturaleza de los paratextos, título incluido. No me parece descabellado encontrar en este punto una respuesta hipotéticamente razonable al «silencio» de Eduardo García sobre la definición de los títulos, su naturaleza o su función: como conjuro de la inminencia (la primera, la del poema que abre), es el espacio del umbral, del límite cuya definición o esclarecimiento representaría su neutralización. Elemento liminar del poema, el título es la frontera en la que el texto roza con la realidad exterior, delimitando su perfil, pero también es su horizonte, la apertura del espacio por el que el poema puede dilatarse, como un precipicio, en su primera dimensión, como un desierto, en la segunda.

En este punto resulta oportuna una reconsideración sobre la obra de Eduardo García y su trayectoria. Desde su aparición en primerizas entregas colectivas de la joven poesía cordobesa de principios de los años 90 hasta su temprano fallecimiento en 20I6, seis fueron las entregas poéticas de nuestro autor, en su práctica totalidad ligadas a premios de prestigio, aparecidas en las editoriales y colecciones de mayor visibilidad y reconocimiento y merecedoras, tras su aparición, de galardones codiciados². Todo ello suponía una

2 La referencia de sus obras se encuentra en la bibliografía citada. Baste ahora citar que Las cartas marcadas ganó el Premio Ciudad de Leganés; No se trata de un juego fue Premio Juan Ramón Jiménez y Premio Ojo Crítico de Radio Nacional de España; Horizonte o frontera mereció 
solvente sanción por la crítica de la calidad de su escritura, pero, en perspectiva, también nos habla de la cuidadosa atención con que el poeta concebía el crecimiento de su obra, sin pasos en falso, con un rumbo que se va haciendo más perceptible con la sucesiva aparición de publicaciones. Si, como revelan los propios títulos de los libros, cabe ver en el conjunto una progresión coherente desde la lucidez de una mirada desconstructiva hasta la altura de lo visionario, no es menos cierto que, observados en su dialéctica con el conjunto, cada título se nos impone como una bisagra, una inflexión en el camino, un avance con algo de giro. Las cartas marcadas se presentan como una primera entrega a partir de la profundización en la conciencia del artificio, con referencias a la máscara, la paradoja y el tahúr, en un verdaderro ejercicio de desnudamiento de las falacias, al tiempo que señala la relación dialéctica con el azar y la representación ficcional. La contradicción ínsita en esta conciencia aflora con No se trata de un juego, una negación menos dirigida a la condición del artificio que a la idea de su intrascendencia: juego sí, pero con toda la seriedad de la partida de ajedrez que jugaba el caballero en El séptimo sello de Bergman. La ambivalencia del título se proyecta en el siguiente, con claras resonancias de Vicente Aleixandre: ¿alternativa o identificación? ¿cuál es la relación entre los dos términos de Horizonte o frontera? En cualquier caso, el libro hace honor a su nombre y marca con nitidez una diferencia entre el discurrir de la etapa inicial (dos entregas en la última década del milenio) y un espacio abierto en el comienzo de un nuevo siglo, una línea de separación y, a la vez, un punto de fuga, un destino en la distancia. Con Refutación de la elegía Eduardo García atraviesa la frontera y deja atrás un tono personal, un género y toda una poética, la dominante en las dos décadas finales del siglo xx. La conciencia del juego de los dos primeros libros aparecía teñida de un tono de melancolía, propio de la pérdida de la inocencia, de la figuración de paraísos abandonados, algo que llegaba a configurar los poemas en clave genérica elegíaca, como una decatación de una tonalidad experiencial que comienza en poetas de los 50 y coagula en la lírica de la otra sentimentalidad; su refutación implica en el poeta un cambio vital, un giro en su actitud ante la realidad, pero también el paso de una frontera y la propuesta de un horizonte con algo de celebración o, cuando menos, de abandono del lamento melancólico. No en balde su nuevo título es La vida nueva, una declaración de principios en sí misma, con la fusión de un programa vital y una propuesta poética, con la referencia a Dante de por

el Premio Antonio Machado; La vida nueva fue Premio Fray Luis de León y Nacional de la Crítica; y Duermevela ganó el Premio Ciudad de Melilla. Para la recomposición del mencionado entorno cordobés valga citar las antologías y estudios de Lostalé (2003) y de Chivite y Barquero (2010), con la bibliografía allí contenida. En La lluvia en el desierto se recogen referencias a algunas antologías personales; las colectivas en que fue incluido son numerosas. Para el acercamiento crítico puede consultarse Ruiz Pérez (2019). 
medio y, con ella, de su periplo por los espacios infernales y celestiales, de su aventura por lo desconocido, que traviesa límites y fronteras para descubrir nuevos horizontes. Estos quedaban ya prefigurados en el ensayo publicado tres años atrás. Una poética del límite miraba, sin duda, hacia adelante, a la línea del horizonte, como Escribir un poema venía a coagular en forma de consejos técnicos la reflexión metapoética (y algo de metafísica) de los poemarios de los noventa. La materialidad del poema denota su condición de artificio y reclama el dominio técnico de su construcción, de su juego. Como límite, el poema se presenta como un vacío, una puerta a la indagación y el descubrimiento; construirlo bien, sí, pero no como una finalidad en sí mismo. El poema es como la casa en el árbol’ ${ }^{3}$ que tiene que levantarse con cuidado (en todos sus sentidos), pero que está hecha para ser habitada, para acceder a una realidad diferente a la que se deja a nivel de suelo. Sueño o viaje onírico, la experiencia poética y su plasmación en el texto no se desprende del todo del principio de la lucidez racional, incluso cuando emprende la aventura del vuelo; de ahí la condición apuntada en el último de sus títulos, Duermevela, ese lugar de frontera, ese límite entre dos realidades que no se excluyen, el espacio donde las reglas del juego ya no admiten unas cartas marcadas, porque nada está escrito.

Este repaso por una producción que puede resultar bien conocida para algunos lectores es una forma relativamente objetivada de sustentar el carácter representativo de la poesía de Eduardo García en lo que ha sido el devenir de las líneas de fuerza de la poesía hispánica en las tres últimas décadas ${ }^{4}$, por no entrar en la discusión sobre el protagonismo que en dicho devenir le corresponde a nuestro poeta. Sobre esta base, también pretendía apuntar el cuidado del autor en el diseño de su producción como un conjunto y, en particular, por unos títulos que, como requería del primer verso en sus consejos al poeta novel, aúnan la referencia y la capacidad de sugerencia, aportando a la vez claves, focalizaciones y, en no escasa medida, ambivalencias incluso contradictorias. En sus procedimientos juega un papel de relieve la presencia de los motivos que adquieren centralidad en su poesía, e incluso conforman un discurso que podemos reconstruir sintagmáticamente. El procedimiento gana en intensidad y valor en las obras más maduras, en una secuencia de ahondamiento que afecta conjuntamente a la posición lírica y al dominio técnico de los recursos del poema, incluida la titulación.

3 «Casa en el árbol», de La vida nueva, es uno de los poemas más emblemáticos del autor.

4 En La lógica de Orfeo Luis Antonio de Villena (2003) apunta la línea de convergencia de las raíces realista y órfica en la poesía que se configura en esos años, reservando un lugar destacado a Eduardo García aun antes de que este sacara a la luz Una poética del límite. 


\section{No (solo) es un juego}

Volviendo a los procedimientos actuantes en los títulos de los poemas, unas últimas calas nos permitirán acercarnos a unas conclusiones. Será la primera la dedicada a los cambios introducidos en el primer poemario publicado de cara a su incorporación en un volumen de poesía reunida. Si bien La lluvia en el desierto (2017) fue el resultado póstumo de un indeseado final que le impidió al poeta ver materializado su propósito, sus páginas respetan la última voluntad de Eduardo García en lo tocante a la refiguración de su poesía inicial. Dos son las alteraciones de calado que entre 1995 y 2016 se introducen en Las cartas marcadas. La primera es la supresión de algunos poemas; el procedimiento no es inusual en este tipo de reediciones, pero llama la atención la intensidad con que nuestro poeta utiliza las tijeras con veinte años de perspectiva y tras una intensa experiencia poética. De los 28 poemas que componían la entrega de 1995 quedan excluidos 5 poemas individuales y una sección completa, la II, «Envío», que contenía originariamente otros dos poemas; es decir, ha desaparecido una cuarta parte de los textos, con alteraciones sustanciales en la arquitectura del libro. Más singular, y significativo a nuestro propósito son las alteraciones que se produce en los títulos, concretamente de tres de los poemas. Comencemos notando que uno de los textos suprimidos en la compilación final es el que lleva por título «Intemperancia que el poeta se permite a despecho del buen tono, solicitando, humilde, la indulgencia del lector», sin discusión el título más atípico en la obra de Eduardo García a la vez que con muy evidentes referencias a una forma de rotular que indica la raigambre de la tradición en la que se insertan los pasos iniciales de nuestro autor, con una clara presencia de Ángel González ${ }^{5}$. Es obvio que la supresión del poema no se debe exclusivamente a las peculiaridades de su título, que podría haber cambiado mientras el resto del texto se mantenía; también se aprecia que en la poesía de Eduardo García (no solo en la suya) la concepción del título y su realización textual están en estrecha relación con la poética más o menos consciente en la que se sitúa el autor. El poema en cuestión, como el título, tenía mucho de laboratorio de indagación metapoética, en unas dosis y con un carácter explícito de poca pertinencia a la hora de recomponer un camino y pulir su coherencia. La operación aplicada a un poema de título peculiar apunta algunas de las claves en el sentido de la manipulación de los tres poemas que, conservándose, pagan el peaje de una revisión de los rótulos que los presentan e inician.

Por orden de aparición de los poemas, los cambios se inician con el que apareció como «La isla» en 1995 y reaparece en 2017 como «Mujer de carne y sueño». De un lado, el primer verso («Tus caricias. El mar. Los cocoteros.»,

5 Pienso en títulos como Muestra, corregida y aumentada, de algunos procedimientos narrativos y de las actitudes sentimentales que habitualmente comportan, Madrid, Turner, 1977. 
tan propio del modelo aconsejado en Escribir un poema) confiere al título inicial un exceso de redundancia, al tiempo que una limitadora especificación: demasiada identificación con una idílica imagen de vacaciones tropicales, algo que está en el código del poema, pero sin la esencialidad de un núcleo temático. Por el contrario, el nuevo y definitivo título no rompe la coherencia del poema, pero remite la relación semántica fundamental a los versos finales («Cuantas mujeres hay en este mundo / las conocí por ti. En ti dormían»), con un efecto de retrospección con los ecos del segundo verso («La sábana enredada entre tus piernas»), que parte de una materialización, la cama, propia de las vacaciones (descanso y sexo), y el enredo de la sábana para remitir a una semántica más compleja. Con el cambio el foco del título gira del escenario a su protagonista, al tiempo que cambia la vaguedad incontralada del símbolo, la isla (Tomé 1987), por una referencia que genera su polisemia en la dialéctica de materia y ensoñación que ya caracteriza la poética de Eduardo García cuando aborda la relectura y reescritura de su producción inicial.

El segundo poema que pasa a su versión final con un título renovado es el soneto que actualiza la tradición filográfica del género áureo, actualizando en clave paradójica y ajena a la incuestionada fidelidad las tensiones del amor y del deseo. Este es su texto, sin título:

Me pregunto si soy un pervertido

sin mucha convicción, pues no lamento

mis tendencias, ni tengo el sentimiento

de culpa que debiera haber fingido.

El caso es que me siento, amor, vencido

por tu cintura breve y por tu aliento

al contemplar el blando movimiento

de un cuerpo tentador, desconocido.

Yo no sé si es delito o si es codicia

carnal este deseo equivocado.

IO

No estaba en el guión la paradoja.

Sentirme triste amante que acaricia tu ausencia en otra piel, enajenado.

Un corazón que el cuerpo desaloja.

El rótulo inicial era «Error de cálculo», y es sustituido por otro tecnicismo en forma oracional: «No estaba en el guión». El desplazamiento es significativo y revela la creciente maestría del poeta y su dominio de la composición, y en especial la importancia otorgada a la revisión de este componente que puede ser el último en integrarse en el texto (en la revisión es, 
claramente, el caso) y que es el primero que encuentra el lector para orientar su experiencia. En este caso también denota el giro en la poética de Eduardo García. La diferencia fundamental entre ambas formulaciones es la desaparición del protagonismo del sujeto, el lírico y el autorial. La mención de «error» implica un juicio, de valor moral o ligado a un contraste de corrección, a un criterio de comportamiento, subrayado por la racionalidad del «cálculo». El «guión», en cambio, remite a una instancia ajena al sujeto u objetivada en relación a él, sin incidencia de quién es el autor de esa previsión, rota, además, por la aparición de un elemento que se remite al azar, a un funcionamiento aleatorio sin la carga de valoración que supone «error». Por otra parte, al extraer del verso ir la frase que se eleva como seuil, el sujeto autorial renuncia su potencia creativa, ostentada en primer título, en favor de una labor más estrictamente editorial, un subrayado que afecta tanto al sintagma entresacado como a la última palabra del verso, de rima difícil y marcada sonoridad, que resume en realidad la semántica del poema.

La no insignificancia del título se entrevé incluso cuando las correcciones parecen ser meramente superficiales, casi de maquillaje. Ocurre así con la breve composición que cierra el libro y que en su título inicial remitía directamente a las «cartas marcadas» del título del libro ${ }^{6}$ :

\section{PARADOJA DEL TAHÚR}

Yo deseaba ser aquel que soy.

Ahora quisiera ser quien me soñaba.

Daría estos renglones sin dudarlo

por recobrar las vidas que perdí.

El cambio introducido en la reedición es mínimo en su dimensión material, pero se carga de significación en la poética de Eduardo García, en lo material, con su cuidadosa atención a la arquitectura del libro y el papel que en ella juegan los títulos, y en lo más profundo de un camino que se aparta de la intrascendencia lúdica. Al suprimir el determinante la reedición evita una redundante y limitadora recurrencia con el título de la composición inicial «El tahúr»; al tiempo, aisla y destaca un sustantivo que va ganando peso en la poética que se aproxima al límite y al escurridizo y ambivalente espacio de la duermevela. Y el lector vuelve a encontrarse con el término que el procedimiento de lima señalado antes ha destacado. El sendero lírico de Eduardo García se reorienta desde los escenarios iniciales de una poesía consciente de su condición ficcional a un espacio entrevisto en un comprometido desdoblamiento.

6 Y hasta diríase que prefigura el título y la reflexión del siguiente, No se trata de un juego, incluso su paradójica ambigüedad. 
Tras la profunda remodelación de Las cartas marcadas en su reaparición como parte de La lluvia en el desierto, adquiere relieve significativo la sistemática renuncia a otras modificaciones en el resto de los títulos. Lo que en ello hay de indicio de la rapidez con que Eduardo García alcanzó un alto grado de dominio de su escritura nos permite un último acercamiento a sus juegos con la titulación desde la convicción de que no se trata de un azar. En No se trata de un juego nos encontramos ya con ese procedimiento de mise en abyme que convierte un elemento en referencia a través de diferentes niveles de articulación del libro desde su centro íntimo a su margen preliminar. El título de la segunda entrega de Eduardo García en forma de libro arranca del primer verso de un poema («No se trata de un juego. Estoy perdido»), del que se aísla su primer hemistiquio (la primera parte un endecasílabo a maiore, de 7+4) para ganar en ambivalencia y capacidad sugeridora y, con ella, ser alzado a título del poema ${ }^{7}$, a modo de subrayado; de ahí se eleva a la portada del libro, enmarcando el conjunto de composiciones y su sentido unitario. El procedimiento se repite, con algún matiz diferencial, en el libro siguiente, Horizonte o frontera. Quizá sea esa situación límite, de conciencia de precariedad entre dos espacios que no acaban de definirse como iguales o como contrarios, la que demandaba un procedimiento particular de rotulación de la obra, aunque el poeta no renuncia al camino ensayado. En este caso se vuelve a tomar la primera parte de un verso inicial, el alejandrino "Al fondo del poema hay un temblor agazapado», para enmarcar y definir la composición, y se vuelve a usar una forma de reticencia consistente en focalizar sobre la parte del verso que no asciende al título el núcleo de una significación caracterizada por la indefinición, latente en la imagen del «temblor agazapado», que da sentido a la apertura de una dimensión oculta, enunciada por el sintagma que pasa a ser título del poema y de la sección tercera del libro. Si la vista del lector sigue este movimiento reparará en el modo en que las seis secciones incorporan títulos que, compartiendo campo semántico, recomponen y proyectan la imagen elegida para identificar el libro, así como la primera de sus partes. Tras «Horizonte o frontera», que reitera al lector la centralidad del concepto (también en sentido graciano), siguen «El túnel» (cómo no evocar a Sábato), el mencionado «Al fondo del poema» (¿el otro lado del espejo de Alicia?), «Pasaje al otro lado» (con ecos de Cortázar y el título de su recopilación de cuentos), «Reflejos en el agua» $\mathrm{y}$ «Las puertas» (donde no se extinguen las huellas de las «doors of percepcion» de las que habla William Blake en The Marriage of Heaven and Hell, antes de que

7 De los 226 poemas que la recopilación final reúne de los libros previos, solo 3 continúan sin título desde su primera aparición. De los 223 poemas que aparecen con marbete y lo conservan el número de los que convierten en título el primer verso o parte de él es muy reducido, I8. Esta recuperación de la antigua noción de incipit va perdiendo peso al avanzar la producción del poeta. 
Aldous Huxley lo retomara para su ensayo y sirviera para nombrar el grupo de Jim Morrison y Ray Manzarek). Lejos del lucimiento erudito, esta recomposición de una tradición pone el énfasis en el movimiento de atravesar y la existencia de una doble realidad que puede fundirse, interpenetrarse, como el lector (y antes que él, el poeta) puede convertir la materialidad del poema en la puerta de acceso al espacio que se encuentra en la trastienda del texto, al otro lado, como una invitación a la experiencia de indagación (break on through to the other side).

La paradoja late también en el título elegido para la recopilación de la obra poética, incluida la inédita o dispersa en revistas. Y, como en los casos anteriores, La lluvia en el desierto ha seguido un curso que le ha llevado a atravesar los círculos de la estructura poemática y de su función. En este caso el sintagma no procede del primer verso ni de ningún otro punto del desarrollo textual del poema; más bien, con su valor entre oximórico, paradójico y taumatúrgico, designa desde el preliminar el no-lugar, la realidad no nombrada intuida «al fondo del poema», un espacio pendiente de definir al otro lado del texto, como ocurre con una engañosa y opresiva realidad fenoménica: «Bajo la indiferencia y el hastío / se oculta una emoción sin explorar». El título del poema da nombre también a la sección que abre, antes de ascender, a modo de requintada selección, a la portada del volumen de poesía completa, definiendo la «poética del límite» alcanzada por el autor o, más bien, concretándola en una imagen de lo extraordinario entendido como el momento excepcional donde la naturaleza se abre al margen de sus leyes cotidianas para dejar paso a la maravilla, a la visión en la que el mundo se diluye y alcanza la fluencia que el poema apenas puede encauzar, que el título lucha por represar.

\section{Documento de identidad}

Caminamos ya hacia unas conclusiones. Las observaciones trazadas permiten concluir afirmando la eficaz utilización por parte de Eduardo García de la constitución moderna del título como parte esencial del poema y la dinámica de significación que establece a partir de su doble condición de elemento externo y de parte inseparable de la propia textualidad del poema y, sobre todo, de su performatividad. Lo que era intuición en su primer libro, se asienta en las entregas editoriales posteriores y se desdobla en la revisión (y re-visión) hecha desde la madurez personal y creativa.

En el espacio privilegiado de los títulos observamos también la cristalización de uno de los elementos más destacados en la poesía de nuestro autor, la ironía, y, sobre todo, de la deriva que esta forma de mirada va adquiriendo en su escritura, a partir de la conciencia lúdica de la poesía y una posición de distancia crítica respecto a la realidad inmediata, entre el juego 
de las cartas y la sátira que revela el modo en que están marcadas. Bastante de esta mirada desdoblada y de los recursos retóricos que comporta persiste en la escritura posterior de Eduardo García, incluso en el airado alegato de La hora de la ira y la lucidez desgarradora (más aún por la serenidad asumida) de Bailando con la muerte. Sin embargo, ya no se trata de un juego, y, con algo de socrática, la ironía trasciende su más superficial condición retórica para convertirse en una forma de la mirada, una verdadera epistemología, en la clave esencial y etimológica de la eironeia griega (Ballart 1994). La ambigüedad de la conjunción en Horizonte o frontera pertenecería al primer plano, el retórico; la percepción del vínculo de identidad entre dos realidades divergentes pertenece a la capacidad de acceder, siquiera sea en el instante fugaz de la duermevela o de la milagrosa lluvia en el desierto, a aquello que se esconde al fondo del poema, de las cosas, de la mirada. Lo que la lectura de la obra de Eduardo García deja manifestarse con morosidad, con los pasos lentos de una andadura poética de más de dos décadas, se revela de manera fulgurante en los títulos. Las calas realizadas apenas atraviesan el umbral, pero, si no me equivoco, valen para constatar la profundidad del mecanismo y la manera en que se afina.

Una nueva dimensión se perfila cuando, con la mirada en el índice de cada uno de los libros y de la compilación final, recorremos la secuencia que dibujan los títulos de los poemas, cuando rehuimos la tentación de su mera caracterización formal en clave de paradigma lingüístico, y nos dejamos llevar por las posibilidades de una lectura en vertical, como la de los versos de un poema. Por momentos, la línea de lectura que así se nos dibuja sobrepasa la frontera del inventario, de la colección inerte de elementos aislados y dibuja una imagen compleja, formada por el engarce de los sintagmas, y así podemos componer, por ejemplo, «Palabras / de las aristas de la noche / al fondo del poema». Ocurre de manera particular en la que se puede considerar etapa de tanteo, de búsqueda, cuando está más claro lo que se deja atrás que lo que se busca. Un juego con el índice revela los poemas in nuce que componen en su secuencia los títulos de las piezas de No se trata de un juego (o sí):

Un hombre mira a otro en la ventana, esas dos soledades confundidas.

El que cruza la calle, al otro lado, no estaba en el guión.

Tenía que encontrarle en el poema.

Sucede, sin embargo: siempre regresa el criminal.

La vida está en otra parte, en el cuadro. 


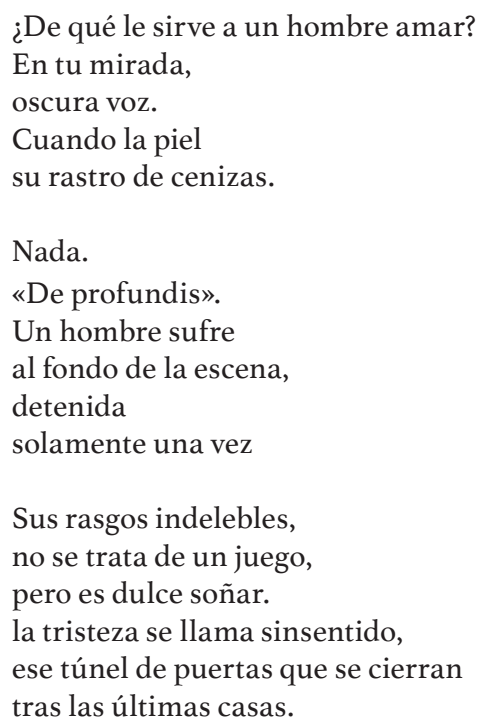

Este ejercicio, pretendido o no por el poeta, revela, en todo caso, la densidad de los títulos en los poemas de Eduardo García y su inserción en un universo de referencia, en un campo semántico e imaginístico que permite una trabazón hermenéutica, un ejercicio de lectura a partir de la que sí es una evidente voluntad de hilvanar los niveles del poemario con títulos en reflejo entre el poema y el libro. El rótulo trasciende el nivel de mero identificador del texto para convertirse en una parte determinante del mismo, un elemento que pone en funcionamiento una dinámica de sentidos en la que el ahondamiento lírico pasa de la connotación a la paradoja, a través de una doble dimensión de la ironía que identifica también las dos tradiciones en que se inscribe la obra del poeta, perceptibles como extremos de su trayectoria, pero en el fondo trabados en intenso diálogo desde sus primeros pasos. Como «horizonte o frontera» del poema, también recoge la razonable mirada a la cotidianidad, sin las estridencias de una pretendida trascendencia, siempre en el borde de la pretenciosidad, y la enlaza con lo que se sitúa en el límite, al otro lado de las puertas del sueño, pero también en sus puertas mismas, como el título en el poema. En «duermevela». 


\section{Bibliografía citada}

Ballart, Pere (I994), Eironeia. La figuración irónica en el discurso literario moderno, Barcelona, Quaderns Crema.

Besa Camprubí, Josep (2002), El títol y el text. Una tipologia dels efects del títol en el text en poesia (tesis doctoral), Barcelona, UAB; consultable en https:// www.tdx.cat/handle/10803/4826 [2.6.2018]

Chivite, Eduardo y Barquero, Antonio (20I0), Terreno fértil. Un ámbito poético (Córdoba, 1994-2009), Sevilla, Cangrejo Pistolero.

Dijk, Teun van (I980), Las estructuras y funciones del discurso, México, Siglo XXI.

Duchet, Claude (1973), «La Fille abandonnée et La Bête humaine: éléments de titrologie romanesque», Littérature, I2, pp. 49-73.

García, Eduardo (1995), Las cartas marcadas, Madrid, Libertarias.

-. (1998), No se trata de un juego, Diputación Provincial de Huelva.

-. (2000), Escribir un poema, Madrid, Fuentetaja.

-. (2003), Horizonte o frontera, Madrid, Hiperión.

-. (2005), Una poética del límite, Valencia, Pre-textos.

-. (2006), Refutación de la elegía, Málaga, Antigua Imprenta del Sur.

-. (2008), La vida nueva, Madrid, Visor.

-. (2014), Duermevela, Madrid, Visor.

-. (2014), Las islas sumergidas, Granada, Cuadernos del Vigia.

-. (20I7), La lluvia en el desierto. Poesía completa (I995-20I6), prólogo de Andrés Neuman y epílogo de Vicente Luis Mora, Sevilla, Fundación José Manuel Lara.

García Aguilar, Ignacio (2008), Poesía y edición en el Siglo de Oro, Madrid, Calambur.

Genette, Gerard (200I), Umbrales, México, Siglo XXI.

Gonzalo Sánchez-Molero, José Luis (2016), «Los orígenes de la portada: un laberinto editorial con una salida inesperada», Titivillus, 2, pp. I27-I56.

Hoek, Leo H. (I973), Pour une sémiotique du titre, Urbino, Centro Internazionale di Semiotica e di Lingüística.

-. (I98I), La marque du titre. Dispositifs sémiotique d'une pratique textuelle, La Haye, Mouton.

Infantes, Víctor (1996), «Tipologías de la enunciación literaria en la prosa áurea: seis títulos (y algunos más) en busca de un género, obra, libro, tratado, crónica, historia, cuento, etc. (I)», en Studia aurea : actas del III Congreso de la AISO, coord. de Ignacio Arellano, Carmen Pinillos, Marc Vitse y Frédéric Serralta, Pamplona, Universidad de Navarra, III, pp. 265-272.

-. (I998), «Tipologías de la enunciación literaria en la prosa áurea: seis títulos (y algunos más) en busca de un género: libro, obra, tratado, crónica, historia, cuento, etc. (II)», en Actas del XII Congreso de la Asociación Inter- 
nacional de Hispanistas, coord. Jules Whicker, University of Birmingham, I998, II, pp. 3IO-3I8.

-. (I996), «Tipologías de la enunciación literaria en la prosa áurea: Seis títulos (y algunos más) en busca de un género: obra, libro, tratado, crónica, historia, cuento etc. (III)», en Actas del IV Congreso Internacional de la Asociación Internacional Siglo de Oro, ed. Ma Cruz García de Enterría y Alicia Cordón Mesa, Universidad de Alcalá de Henares, I998, II, pp. 845-856.

- (2000), «Tipologías de la enunciación literaria en la prosa áurea. Seis títulos (y algunos más) en busca de un género: obra, libro, tratado, crónica, historia, cuento, etc. (IV)», en Actas del XIII Congreso de la Asociación Internacional de Hispanistas, ed. Florencio Sevilla Arroyo y Carlos Alvar Ezquerra, Madrid, Castalia, III, pp. 64I-654.

- (200I), «Tipologías de la enunciación literaria en la prosa áurea: Seis títulos (y alguno más) en busca de un género: libro, obra, tratado, crónica, historia, cuento, etc. (V)», en Actas del V Congreso Internacional de la Asociación Internacional Siglo de Oro, ed. Christoph Strosetzki, Madrid, Iberoamericana, pp. 730-736.

-. (2004), «Tipologías de la enunciación literaria de la prosa áurea: seis títulos (y algunos más) en busca de un género: obra, libro, tratado, crónica, historia, cuento, etc. (VI)», en Memoria de la palabra: actas del VI Congreso de la Asociación Internacional Siglo de Oro, ed. de Francisco Domínguez Matito y Ma Luisa Lobato, Madrid, Iberoamericana, pp. I059-IO7I.

Kamuf, Peggy (I988), Signature pieces: on the institution of authorship, Ithaca, Cornell University.

Lostalé, Javier (2003), Edad presente. Poesía cordobesa para el siglo XXI, Sevilla, Fundación José Manuel Lara.

Martín Puya, Ana Isabel \& Ruiz Pérez, Pedro (20I5), «El nombre de la cosa: títulos, modelos poéticos y estrategias autoriales en el bajo barroco», Criticón, monográfico Paratextos y sociedad literaria, I25, pp. 25-48.

Reyes Gómez, Fermín de los (2000), El libro en España y América: legislación y censura (siglos XV-XVIII), Madrid, Arco/Libros.

Roy, Max (2008), «Du titre littéraire et de ses effets de lecture», en Le titre des oeuvres: accesoire, complément ou suplément, monográfico de Protée, 36, 3, pp. 47-56.

Ruiz Pérez, Pedro (2009), La rúbrica del poeta. La expresión de la autoconciencia poética de Boscán a Góngora, Universidad de Valladolid.

-, ed. (2019), Escribir el límite. La poesía de Eduardo García, monográfico de Anales de Literatura Española, 3I, en prensa.

Tomé, Mario (1987), La isla: utopía, inconsciente y aventura. Hermenéutica simbólica de un tema literario, León, Universidad de León.

Villena, Luis Antonio de (2003), La lógica de Orfeo, Madrid, Visor. 